\footnotetext{
A AndragošKe studije, issn 0354-54I5, Broj i i, Decembar 2018, str. 29-44

(c) Institut Za pedagogiju i andRagogiju; Originalni naučni rad

UDK 374.7:502.131.I-053.85/.9-055.2(66)

DOI: $10.5937 / A N D S T U D i 802029 \mathrm{~A}$
}

Elizabeth Aanuoluwapo Ajayi ${ }^{1}$, Adekunle Olatumile ${ }^{2}$

Adekunle Ajasin University Akungba-Akoko, Ondo State, Nigeria

\title{
Indigenous Folklores as a Tool of Transformative Learning for Environmental Sustainability in Nigeria
}

\begin{abstract}
Unsustainable environmental practices abound even with efforts majorly concentrated on formal strategies. However, there are local strategies such as indigenous folklores frequently used by elderly women which can be transformative. The study assessed Yoruba folklores as a potential tool for promoting transformative learning with regards to environmental sustainability. It employed a cross-sectional survey design involving 200 elderly females in ten communities of the Ondo North Senatorial District. The six research questions raised for the study were answered descriptively using a 15 item questionnaire. Among other things, the findings revealed that environmentally inclined indigenous folklores have the potential to create a conscious and critical reflection of environmental situations as well as help develop action plan towards environmental sustainability. Additionally, it was recommended that folklores should be incorporated into all efforts towards environmental sustainability with the support of elderly women.
\end{abstract}

Key words: elderly women, environmental education, Indigenous Folklores, transformative learning, environmental sustainability.

\section{Introduction}

One of the states in the south-western part of Nigeria that has predominance of the Yoruba race is Ondo State. The state's environment is characterized by coastal plains, mountains, water bodies and the interaction of humans with them. This is important and valuable for the socio-economic development of nations. Moreover, it has brought about the issue of environmental sustainability as an international and national discussion for decades. Environmental sustainability

\footnotetext{
${ }^{1}$ Elizabeth Aanuoluwapo Ajayi is a doctoral student at the University of Benin and a lecturer at the Faculty of Education, Adekunle Ajasin University Akungba-Akoko, Ondo State, Nigeria (elizabeth.ajayi@aaua.edu.ng).

2 Adekunle Olatumile is a lecturer at the Faculty of Education, Adekunle Ajasin University Akungba-Akoko, Ondo State, Nigeria (adekunle.olatumile@aaua.edu.ng).
} 
can be described as a condition of balance, resilience, and interconnectedness that allows the human society to satisfy its needs without exceeding the capacity of the supporting ecosystems to continue generating services without diminishing biological diversity (Morelli, 2011). It simply refers to a deliberate attempt to utilize the environment and its resources in a manner that would be useful for future generations and not harmful to the environment.

The call for environmental sustainability around the world is as a result of human activities, some of which in Ondo State are: bush burning, exploration of petroleum products, constant use of firewood for cooking (which releases toxic gases into the atmosphere), dumping of waste in water bodies, fumigation, lumbering/tree felling, hunting, improper building layout, and cow overgrazing, among others. These activities have contributed to natural and animal resources depletion, overgrazing, pollution of air, water and soil, climate change and global warming, deforestation, desertification and the loss of biodiversity, among other things.

Most of these challenges are attitudinal and there have been several efforts at the international, national and state levels trying to correct it. For instance, in Ondo State there is the effort of compulsory environmental sanitation exercise every last Saturday of the month (which citizens often use as a period for relaxation). Being an oil producing state, Ondo State benefits from the Petroleum Acts which saddles the Ministry of Petroleum resources with the responsibility of promoting environmental awareness through a biennial seminar on the petroleum industry and the Nigerian environment (Federal Government of Nigeria, 1997). In addition to these, the Ministry of Environment and Mineral Resources is saddled with the responsibility of providing sustainable physical policies on environment and solid mineral mining. Furthermore, sanitation officers known in Yoruba as wo le wo le move around markets on Thursdays to ensure sanitation exercise is observed. Another effort by the Nigerian government is the inclusion of environmental education in the formal education system. Okupkon (2008) noted that environmental education was integrated into the Nigerian school curriculum (primary, secondary and tertiary) and adopted in February 1998 to have dimensions in virtually all school subjects.

Aside from formal education and methods, there have been recommendations at an international level to inculcate traditional and non-formal education in the learning of environmental sustainability. One of such is the Agenda 21, which is the action plan adopted by world leaders after the United Nations Conference on Environment and Development in 1992 held in Rio, Brazil. Chapter 26 of the document encouraged nations who want to achieve sustainable development that they need to recognize the role of indigenous people and their communities (UN, 1992). Moreover, a treaty was derived from the Earth Summit of 
1992, titled The Convention on Biological Diversity. This document recognized the close dependence on local and traditional communities and the use of traditional knowledge, innovations and practices relevant to biological diversity and sustainable purposes. One of the local indigenous learning channels and people are women who are 60 years and above. They have been socialized into unsustainable environmental practices yet they have vital transformative learning skills for environmental sustainability.

This group of indigenous people have spent decades on earth and by virtue of their gender role, have interacted more with the environment than their male counterparts. This makes them more aware of the pains of unsustainable environmental practices. Elderly women are believed to have raised generations and they have holistic traditional scientific knowledge (inherited from previous generations) of their natural resources and the environment. It is noted that elderly women are knowledge keepers with their awareness of indigenous methods of sustainable practices in the production of indigenous crops (Debwa \& Mertens, in Okolo, Mamman \& Ekpo, 2017). Hence, these indigenous people are empowered with values and traditional environmental management knowledge to promote environmental sustainability. These qualities make them better in giving wise counsel, protecting heritage, teaching cultural values, and being the custodians of traditions which are educational in nature. One of such traditions important for environmental sustainability are indigenous folklores which women use frequently. Barau, Stringer and Adamu (2016) asserted that women use folklores and other indigenous knowledge more than their male counterparts.

In Ondo State, as well as other Yoruba lands, this oral tradition of folklore which is associated with beliefs and myths serves as a source of entertainment, enlightenment on cultural orientation and traditions of the people and educates the young about the various aspects of society. Yoruba folklores considered in this study come in form of owe (proverbs), alo apagbe (stories with songs), alo apamo (witty words or riddles), orin (songs) and ewi (poems). These selected folklores perform didactic, entertainment, enlightenment and educational functions, among others. They create opportunities for the young and old to interact, while the young learn from the events of the folklores. The words in folklores usually give insight into its origin, which often depicts a desire for a change in attitude, not just the entertainment.

The issue of attitudinal change is the main result derived from transformative learning, which is a process that uses prior interpretation to construct a new or revised meaning of one's experience in order to guide future action (Merten, 2014). It involves a mental construction of experiences, that is, thoughts about situations had over the years and a critical reflection that comprises an analysis 
of constructed experiences, as well as the development and implementation of action plans for positivity. The strategy of using environmentally inclined Yoruba folklores such as 'Omi wo yanrin' (Flowing water washes away sand) among others may be useful in changing unsustainable practices within the environment.

Although there have been international recommendations for the use of indigenous people (their knowledge and experiences) and the use of indigenous processes to achieve sustainable development, it can be observed that emphasis is still on the formal processes towards environmental sustainability. Olatumile (2009) noted that the concentration on formal education and a lack of holistic approach may be the reason why effective and efficient results have not been achieved in curbing environmental issues. Therefore, since regular learning methods have not achieved desired transformative results, there is a need to shift emphasis to indigenous people and processes. This study considered elderly women as indigenous people who are frequent users of folklores as an indigenous process that may bring about environmentally transformative potentials towards sustainability.

Hence the purpose of this study was to assess Yoruba folklores as a potential tool for promoting transformative learning with regards to environment sustainability. Specifically, it was set to answer the following research questions:

1. What is the level of elderly women's knowledge on environmentally inclined folklores?

2. Do Yoruba poems enhance the mental construct of experience on environmental sustainability?

3. Do environmentally inclined Yoruba riddles promote the mental construct of experience on environmental issues?

4. Do environmentally inclined Yoruba folklore songs improve critical environmental reflection?

5. Do Yoruba folklore stories facilitate critical reflection on environmental sustainability?

6. Do environmentally inclined Yoruba proverbs influence the development of action towards environmental sustainability?

\section{Concept of Transformative Learning}

The drive for transformative learning started with the Brazilian educator Paulo Freire with his concept of conscientization. American Jack Mezirow complemented Freire's work when his wife enrolled back in school to complete her undergraduate education. Through thick and thin, she finished her studies and this transformed her life economically, socially and in all ramification, because 
she continued her studies further and served in various managerial capacities in USA (Kitchenham, 2008). This formed part of the basis for the transformative learning concept and theory by Meizirow, when his research concluded that women had undergone personal transformation and delineated a series of phases of change that included a disorienting dilemma, a critical assessment of assumptions, exploration of options for new roles, and building competence and selfconfidence in new roles and relationships (Kitchenham, 2008; Ivying \& English, 2011; Levine, 2014).

The concept of transformative learning argues that learning to think for oneself involves critically reflecting on assumptions and participating in discourse to validate beliefs, intentions, values and feelings (Mertens, 2014). Therefore, transformative learning is a process that involves habits of the mind and meaning perspectives which lead to the transformation of current perspectives. This process requires attaining awareness of specific assumptions of distorted or incomplete meaning through a reorganization and transformation of the meaning (Kitcheham, 2008). Specifically the scope of transformative learning covers three major components of the mental construct of experiences throughout life, critical reflection about these experiences and what can be done to use them positively to influence the future, development and implementation of action by trying out new knowledge, skills and roles to build self-confidence and improve the quality of life.

These are important for this study because in practice, elderly Yoruba women encounter environmental challenges and anomalies which cannot be resolved through the present meaning of the situation but through resolutions that come from the redefinition of the problem based on experience. Hence, transformation comes from the elderly women's ability to examine the worldview of environmental issues in light of their own particular beliefs or value systems, which include indigenous folklores. Therefore, transformative learning represents an articulation with the past and enhancement of present knowledge, skills or abilities based on inherent knowledge and experiences. This becomes important in the view of adopting the indigenous method of inculcating environmental knowledge, since environmental education must be practical (Kaur, 2014).

\section{Concept of folklore}

Folklores can be described as an oral tradition that also serves as a major vehicle for expression and positive means of transferring knowledge, morals, values and norms from one generation to another (Simeon-Fayomi, 2015). Folklore can simply be described as indigenous knowledge which presents and preserves 
values and is orally transmitted from one generation to another along with its educational and utilitarian values. It serves as a vehicle for transmitting culture, preserving memories and making sense of the world. Bauman (2008) noted folklore to be an expression of culture shared by a group of people. It includes oral traditions such as jokes, tales, and proverbs. It is further noted that these folklores are often not taught in formal school curriculum, but are rather passed informally from one person to another through verbal or body languages. They are known for their oral tradition of moonlight stories and other folklores which consist of past, present and future activities that are useful for inculcating knowledge.

Folklores being oral tradition, universal wisdom, and fun, have deep underlying structures which makes them instrumental for application to life issues (Nagy, 2015). They are an innovative indigenous process that serves as a potent means of learning because they apply to everyone regardless of their age or educational status. They include, but are not limited to owe (proverbs) which are short sentences conveying well-known wisdom, truth, morals, and traditional views in metaphor used either with or without change. They also comprise alo apamo (witty words or riddles) which is a statement or question put forth as a puzzle to be solved, ewi (poems) that is a form of literature which uses language aesthetic and evocative qualities, alo apagbe (stories with songs), and orin (songs). With folklores, citizens can be conscientisized to identify its inherent qualities and be exposed to bring about changes in their attitude towards the environment (Olatumile, 2009). These can be achieved when folklores are channelled for the construct of their environmental experiences over the years, critical reflection of the present environmental situations, development of an action plan for improvement and implementation of developed action in a learning situation towards a sustainable environment.

\section{Environmental transformative learning tools inherent in folklores}

Folklores have transformative characteristics that can be used to bring about positive changes in the attitude of both old and young towards the environment. They help to instil a sense of belonging, patriotism and identity to every tribe. Furthermore, the settings of folklores are designed to increase people's awareness and diversity of the culture and geography which includes the environment. Penjore (2005) noted that listening to folklores momentarily transports the audience to a different world where they reflect and connect it to the real world, which is one of the key component of transformative learning. Doriji (2005) stated that 
folklores give insights into the relationship between man and his natural environment. Mphsha (2015) observed that folklores are environmentally inclined because they are the results of observing human nature, containing fundamental truths about life as observed by people in ancient times. Barau, Stringer and Adamu (2016) conclude that environmental ethics are found in folklores and they can be used to address multiple sustainability threat through grassroots informed actions and attitudes that contribute towards transformation for sustainability.

Indigenous folklores, such as the Yoruba songs witty words, poems among others, are often reflections of the mind. This was confirmed by Mpsha (2015) in the Strengths, Weaknesses, Opportunities and Threats (SWOT) analysis of the cultural value of folklores. It was noted that every folklore is a lesson which is reflective of the user's state of mind. It was also confirmed that they show aspects of the society which people show least awareness of because they are part and parcel of people's life which cannot be taken for granted. These aspects can be seen as environmental experiences people encounter daily but take less cognisance of. Folklores give an opportunity to mentally construct these experiences and make meaning out of them. Simeon-Fayomi (2015) noted that the power of folklore stories contains a transformative learning device due to its high level of imagery technique. This is in line with the critical reflection present in the component of transformative learning. Mphsha (2015) noted that the collection of values opens people's eyes to their immediate environment. Hence, people have the power to start a dialogue with their world and people within their world. Ajayi (2017) supported this by stating that indigenous riddles, poetries and proverbs, among others, are high cognitive activities which are needed for critical reflection and contextualization to identify appropriate responses and meaning.

Furthermore, Mphsha (2015) noted that folklores enhance people's awareness of their shared historical knowledge systems, and place them in a stronger position to participate in decision-making and negotiations on the issues that have an impact on them. This historical knowledge system includes issues around the environment and their challenges because folklores define messages in such a way that they are understandable and relevant to elderly women. Hence, elderly women can participate in the development of action towards the implementation of best environmental practices and instil the same in the younger generation. The combination of all these transformative learning processes in folklore makes it a useful tool for solving personal and societal problems, which in the present day is associated with environmental unsustainability. Olatumile (2009) also noted that folklores have an epistemological view wherein adults (including elderly women) process and construct their ideas. He added that it does not only have an epistemological view but also a transformative one, wherein moral les- 
sons transform lives, based on the components of transformative learning embedded in andragogy.

\section{Methodology}

The design for the study was a cross-sectional survey. The population for the study consisted of females aged 60 years and above residing in the Ondo North Senatorial District of the Ondo State, the total number of which was 25.862 (National Population Commission, 2010). Multistage sampling techniques were used for the study. The first stage was a disproportionate stratified random sampling technique based on Local Government Areas (LGA) and communities to arrive at 10 communities in the Ondo North Senatorial District of the Ondo State. The second stage was a convenience sampling technique used to select 20 participants from each community in the order below for a total of 200 participants:

Table 1: Sample distribution

\begin{tabular}{l|l|l}
\hline Local Government Area & Communities & Sample \\
\hline \hline Akoko North East & Arigidi-Akoko & 20 \\
& Ikare-Akoko & 20 \\
Akoko North West & Erusu-Akoko & 20 \\
& Akunnu-Akoko & 20 \\
Akoko South East & Ipe-Akoko & 20 \\
& Isua-Akoko & 20 \\
Akoko South West & Oka-Akoko & 20 \\
& Akungba-Akoko & 20 \\
Owo & Emure Ile & 20 \\
Ose & Ifon & 20 \\
TOTAL & 200 \\
\hline
\end{tabular}

A questionnaire with 14 closed-ended items and one open-ended item was used as an instrument for the study. 200 participants were given the questionnaire while research assistants helped illiterate participant to read and interpret the questions in Yoruba language to get their preferred responses. Each folklore was mentioned for the participants while they recited and the few who could not recite, were assisted by the researcher. After the recitation, the participants were asked to identify the environmental element while interpreting each folklore. Responses retrieved for research question one were scaled as very good, good, fair and poor based on the average knowledge of each participant about all the 
folklores used for the study. This was analysed using a frequency count and bar chart. Responses for research questions two to five were structured into Agree and Disagree, analysed using a frequency count and mean at a decision level of 1.5, that is, decisions for items with a mean value of 1.5 and above were regarded as positive and vice versa. Responses for research question six were grouped into five subjects and analysed using a frequency count and bar chart.

\section{Results and discussion of findings}

Research question 1: What is the level of elderly women's knowledge on environmentally inclined folklores?

Fig I: Average frequency of participants knowledge level about environmentally inclined folklores

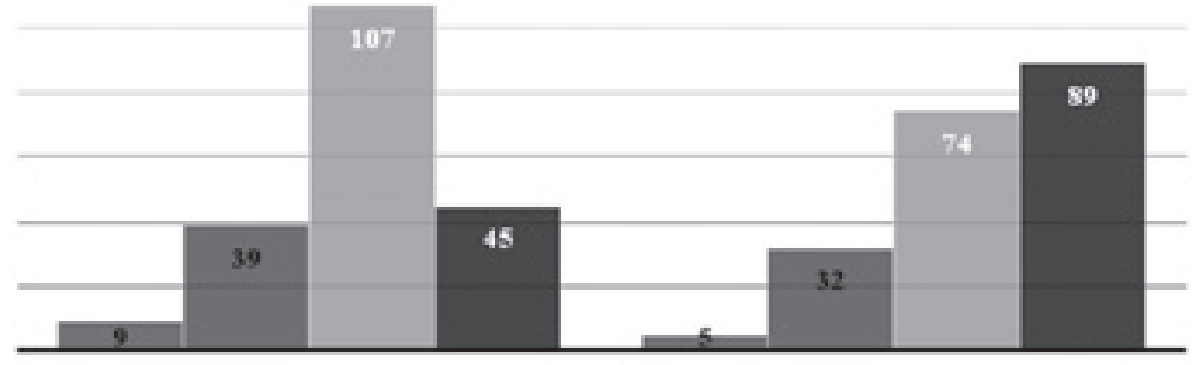

ABIIITY TO RECTTE

ABILITY TO INTERPRETE

= Poor = Fair = Good = Very Good

The results showed that more than a half of the participants have very good and good ability to recite the nine folklores used for the study (Appendix). They also fared well with higher rates in their ability to interpret and use the folklores. This showed that elderly women have a relatively high level of knowledge on environmentally inclined folklores and that they are active users of folklores. This confirms the proposition that since folklores are historically usually passed from the elderly to the younger generation, elderly women have interacted more with the environment and can relate sustainability issues with folklores. This correlates with Barau, Stringer and Adamu (2016) who asserted in their study that women are more frequent users of folklores and other indigenous knowledge than their male counterparts. 
Research question 2: Do Yoruba poems enhance the mental construct of experience on environmental sustainability?

Table 2: Frequency and mean for the use of poems to enhance the mental construct of experience

\begin{tabular}{r|l|c|c|c|c}
\hline S/N & STATEMENTS & A & D & Mean & Decision \\
\hline \hline 1 & $\begin{array}{l}\text { If animals are killed without caution, they will go into } \\
\text { extinction }\end{array}$ & 125 & 75 & 1.63 & Positive \\
2 & $\begin{array}{l}\text { Environmental sustainability will be impaired if animals go } \\
\text { into extinction }\end{array}$ & 157 & 43 & 1.79 & Positive \\
3 & $\begin{array}{l}\text { Unkempt environment leads to untimely death } \\
4\end{array}$ & 164 & 36 & 1.82 & Positive \\
important reaning the house, means of waste disposal is not quite & 35 & 165 & 1.83 & Positive \\
imprand Total & 481 & 319 & 1.77 & Positive \\
\hline
\end{tabular}

Data presented in Table 2 are response items related to Yii ese re si apa kan \& Bo oju re bi o ba ji (Appendix). The responses revealed that each item has a positive mean with a high response of 481 for the total of agreed responses and 319 for disagreed responses. It also showed a grand mean of 1.77 which is positive and supporting the view that Yoruba poems enhance the mental construct of experience on environmental sustainability. The recitation of these poems enhanced the participants' mental construct on unkempt environment and the need to avoid animal extinction through environmentally unsustainable practices. This confirms that folklores enhance the transformative type of learning based on dialogues, encounters and reflections where it connects the learners' perception of the world around them and their inherent knowledge based on experience (Mphsha, 2015).

Research question 3: Do environmentally inclined Yoruba riddles promote the mental construct of experience on environmental issues?

Table 3: Frequency and mean for the use of environmentally inclined riddles to promote mental construct of experience

\begin{tabular}{|c|c|c|c|c|c|}
\hline $\mathrm{S} / \mathrm{N}$ & STATEMENTS & A & $\mathrm{D}$ & Mean & Decision \\
\hline 1 & Bad waste disposal habits attracts flies & 158 & 42 & 1.79 & Positive \\
\hline 2 & $\begin{array}{l}\text { Unsustainable food production can be caused by flies feasting } \\
\text { on food }\end{array}$ & 128 & 72 & 1.64 & Positive \\
\hline 3 & Flooding has respect for persons & 30 & 170 & 1.85 & Positive \\
\hline \multirow[t]{2}{*}{4} & Building across drainages can cause flooding & 163 & 37 & 1.82 & Positive \\
\hline & Grand Total & 479 & 321 & 1.78 & Positive \\
\hline
\end{tabular}


Data presented in Table 3 are the responses to items related to Kilo ba oba jeun \& Kilo ko ja lenkunle oba (appendix). The responses revealed that each item has a positive mean with a high response of 479 for the total of agreed responses and 321 of disagreed responses. The results showed a grand mean of 1.78 which is positive and supporting the view that environmentally inclined riddles promote the mental construct of experience on environmental issues. The riddles promoted the participants' mental construct on the causes of flooding, the strategies to prevent flooding; and ensuring sustainability of the environment through sources of food. Mphsha (2015) confirmed that folklores give interpretation in line with everyday life and activities which reveals to humans the things that have become part and parcel of them which they do not take cognizance of.

Research question 4: Do environmentally inclined Yoruba folklore songs improve critical environmental reflection?

Table 4: Frequency and mean for the use of environmentally inclined songs to improve critical environmental reflection

\begin{tabular}{r|l|c|c|c|c}
\hline S/N & STATEMENTS & A & D & Mean & Decision \\
\hline \hline 1 & Flood destroys faster than fire & 158 & 42 & 1.79 & Positive \\
2 & Flooding cannot be prevented & 55 & 145 & 1.73 & Positive \\
3 & Planting of trees is important for wind breaking & 154 & 46 & 1.77 & Positive \\
4 & Tree felling exposes to direct contact with rays of sun & 157 & 43 & 1.79 & Positive \\
& Grand Total & 524 & 276 & 1.77 & Positive \\
\hline
\end{tabular}

Data presented in Table 4 are the responses to items related to Omi wo Iyanrin and Labe Igi Oronbo (Appendix). The responses revealed that each item has a positive mean with a high response of 524 for the total of agreed responses and 276 of disagreed responses. The results also showed a grand mean of 1.77 which is positive and supporting the view that environmentally inclined folklore songs improve critical environmental reflection. Participants were able to think about environmental situations after singing folklore songs because the participants were able to think about the flooding situation and the gravity of its impact on the destruction of life and property. They were also encouraged to think about the need for tree planting and the ills of deforestation within the society. Mphsha (2015) confirmed that folklores, such as songs, enhance people's awareness of their shared historical knowledge systems, and place them in a stronger position to participate in decision-making and negotiations on the issues that have an impact on them. 
Research question 5: Do Yoruba folklore stories facilitate critical reflection on environmental sustainability?

Table 5: Frequency and mean for the use of stories to facilitate critical reflection on environmental sustainability

\begin{tabular}{|c|c|c|c|c|c|}
\hline $\mathrm{S} / \mathrm{N}$ & STATEMENTS & A & $\mathrm{D}$ & Mean & Decision \\
\hline 1 & Land and water is important for the survival of man & 163 & 37 & 1.82 & Positive \\
\hline 2 & Man can survive without plants & 50 & 150 & 1.75 & Positive \\
\hline 3 & $\begin{array}{l}\text { Sustainable consumption is important for man's survival } \\
\text { within the environment }\end{array}$ & 157 & 43 & 1.79 & Positive \\
\hline \multirow[t]{2}{*}{4} & Land loses nutrients from overcultivation & 147 & 53 & 1.74 & Positive \\
\hline & Grand Total & 517 & 283 & 1.78 & Positive \\
\hline
\end{tabular}

Data presented in Table 5 are the responses to items related to Nigba Iwase Aye (appendix). The responses revealed that each item has a positive mean with a high response of 517 for the total of agreed responses and 283 of disagreed responses. The result showed a grand mean of 1.78 which is positive and supporting the view that Yoruba folklore stories facilitate critical reflection on environmental sustainability. The participants' consciousness was improved on the culture of environmental sustainability because they confirmed that environment has influence on human development and vice versa. They realized that overutilization of the environment and its resources would impede its existence in the future. These findings are in line with Simeon-Fayomi (2015) which opined that folklore stories contain transformative learning devices for critical reflection due to their high level of imagery technique.

Research question 6: Do environmentally inclined Yoruba proverbs influence the development of action towards environmental sustainability?

Fig II: Response for the use of proverbs for environmental action

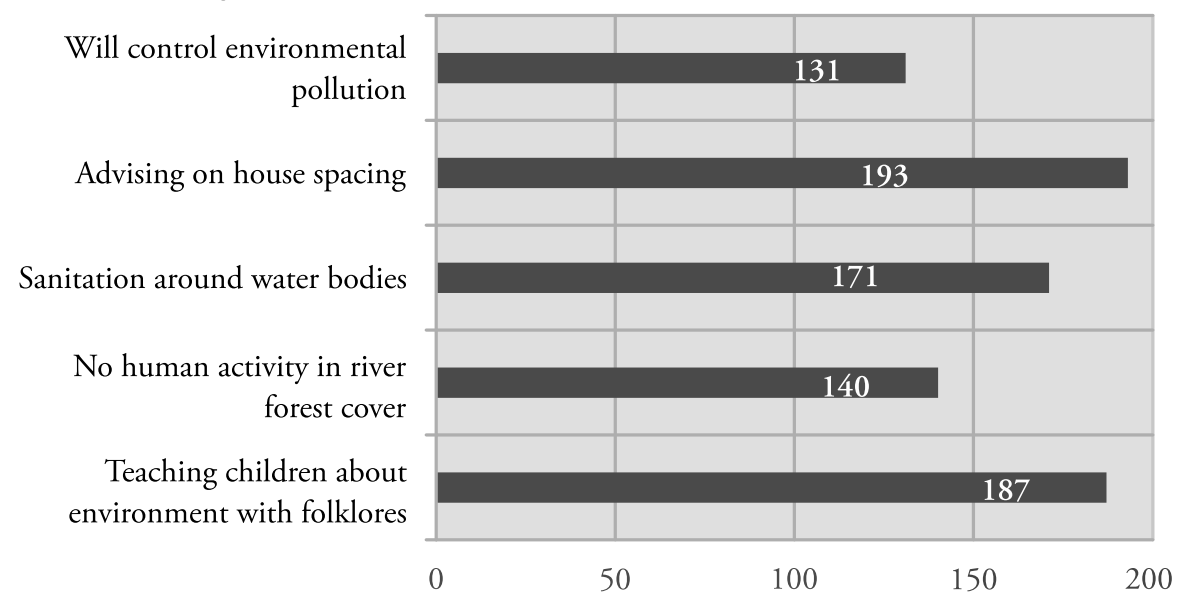


Data presented in Figure II are the responses to items related to Odo to ba gba gbe orison and Bi ile ba kan ile (Appendix). The results showed that environmentally inclined Yoruba proverbs can influence the development of action towards environmental sustainability because all participants had something to say regarding development plans, such as advising on house spacing having the highest number of responses (193), followed by ensuring the younger generations are taught about environmental sustainability using folklores (187), followed by other plans such as pollution control, sanitizing water bodies, ensuring reduced or no human activities around water bodies. The potency of folklore to develop environmental sustainability action is in line with Olatumile's (2009) view that folklores have the power to bring about transformative change in building action for changing the course of environmental challenges. In addition to this, research conducted in 2007 by Husser, Gigliotti and Roberto, revealed that elderly women view that they have the moral responsibility to bring about change in the present course of the environment, hence they are willing to build plans and implement them towards a better environment.

Outside the scope of the research questions, findings of the study also revealed that the participants who are mostly grandmothers may find instilling environmental values into their younger offspring through folklores difficult due to rural urban migration and over-emphasis on English language as a means of communication in schools and homes. Nevertheless, they generally accepted that indigenous folklores serve as a strong tool to inculcate environmental sustainability values and readiness for action in people of all ages.

\section{Conclusions and recommendations}

Based on the findings, although the regular formal method of inculcating environmental sustainability practice is in use, there is a ray of hope for better practices through folklores. Folklores can serve as a means for socialization and inculcating of acceptable environmental behaviours and values among the adults and youths, as well as learning tool for critical reflection and action. The potency of folklores as a transformative tool for positive environmental attitude is non-debatable. The use of indigenous people, including elderly women who are also part of the custodians of these folklores, is also valuable. The elderly women's wealth of folklore knowledge can be tapped into in order to instil good environmental culture in the younger generation and this would aid provide a sustainable environment for the future generation. Therefore, it was recommended that: 
- Indigenous folklores should be mainstreamed in environmental education methods and strategies at all levels of education with inputs from elderly women.

- Indigenous folklores method should be recognized and inputted in national lifelong education policies (primary, secondary, tertiary and non-formal) for all citizens.

- Indigenous folklores should be used as channels for disseminating environmental issues and environmental education even in Information Communication Technologies.

- Media outlets must incorporate the use of folklores in programmes geared towards creating environmental awareness with contributions from elderly women.

- Mass media such as billboards, postal, fliers, handbills meant for creating environmental awareness should have folklores about environmental issues inscribed on them.

- Elderly people should be encouraged to implant environmental folklores in young people through each-one-teach-one method.

- Environmental educational gerontology programme should be implemented across Nigeria incorporating folklores as one of its facilitation method to enhance environmental transformative learning among elderly women.

- The use of Language of Immediate Community (LIC) should be adhered to as it is stated in the National Policy on Education.

\section{References}

AJAYI, E. A. (2017). Innovative Facilitation of Adult Leaning: Indigenous Folklores Method. Paper presented at 2017 winter school on comparative studies in adult and lifelong learning. Wurzburg, Germany.

Amali, H. I. (2014). The function of folklores as a process of educating children in the $21^{\text {st }}$ century: A case study of Idoma folklores. International Conference on $21^{\text {ts }}$ Century Education Proceedings, 2(1), 88-97.

Barau, A. S., Stringer, L. C., \& Adamu, A. U. (2016). Environmental ethics and future oriented transformation to sustainability in Sub-Saharan Africa. Journal of Cleaner Production, 135, 1539-1547. Retrieved from http://dx.doi.org/10.1016/j. jclepro.2016.03.053

Bauman, R. (2008). The Philology of the Vernacular. Journal of Folklore Research, 45(1), $29-36$.

DorJi, T. C. (2005). Preserving our folklores, myths and legends in the digital era. Journal of Bhutan Studies, 2, 93-108. 
Federal Government of Nigeria. (1997). Institutional Aspects of Sustainable Development in Nigeria. Retrieved from http://www.un.org/esa/agenda21/natlinfo/ countr/nigeria/inst.htm

Husser, E. K., Gigliotti, C. M., \& Roberto K. A. (2007). Health, Spirituality and Environmental Concern: Older Women's Perspectives on the Natural Environment. Retrieved from https://vtechworks.lib.vt.edu/handle/10919/24092

IRving, C. J., \& English, L. M. (2011). Transformative learning with women: A Critical Review Proposing Linkages for the Personal and Political Spheres. In S. Carpenter, S. Dossa, \& B. J. Osborne (Eds.), Proceedings of the $52^{\text {nd }}$ National Conference of the Adult Education Research Conference $(A E R C)$ and the $30^{\text {th }}$ National Conference of the Canadian Association for the Study of Adult Education (CASAE) (pp. 305-312). Toronto, Canada: University of Toronto.

KAUR, R. (2014). Why Environmental Education is the need of the day? Retrieved from http://www.mapsofindia.com/my-india/india/why-environmental-education-isthe-need-of-the-day

Kitchenham, A. (2008). The evolution of John Mezirow's transformative learning theory. Journal of Transformative Education, 6(2), 104 - 123.

Levine, J. (2014). Jack Mezirow, Who Transformed the Field of Adult Learning, Dies at 91. Retrieved from http://TeachersCollegeNewsroom/InMemoriam/JackMezirow_Transformed_the_Field_of_AdultLearning_Dies_at_91_TeachersCollegeColumbiaUniversity.html

Mertens, D. M. (2014, March). Transformative Research Approach for Women with Disabilities and STEM in International Development. Paper presented at $58^{\text {th }}$ United Nations Commission on the Status of Women Parallel Event. New York, USA. Retrieved from http://www.womenenabled.org/pdfs/Statements\%20Dona\%20 Mertens\%20\%20STEM\%20\&\%20Women\%20\&\%20Girls\%20with\%20Disabilities\%20CSW58\%20March\%2014,\%202014.pdf

Morelli, J. (2011). Environmental sustainability: A definition for environmental professionals. Journal of Environmental Sustainability, 1, 19 - 27.

Mpнsна, L. E. (2015). Folklores reveal the cultural values of the community: A SWOT (Strengths, Weaknesses, Opportunities, and Threats) analysis. Anthropologist, 19(1), 295-302.

Okukpon, L. A. (2008). Elements of Environmental Education (2 ${ }^{\text {nd }}$ ed.). Benin City, Nigeria: Ambik Press Ltd.

Olatumile, A. (2009). Using storytelling for climate change education. AAU: African Study Review, 8, 227-244.

Оlоко, M., Mamman, M., \& Eкро, R. (2017). Underscoring the role of Nigerian rural women in environmental protection: Lessons from Makarfi in Kaduna State, Nigeria. African Journal of Environmental Science and Technology, 11(5), 213-218.

Penjore, D. (2005). Folklores and education: role of Bhutanese folklores in value transmission. Journal of Bhutan Studies, 2(1), 256-277. 
Simeon-Fayomi, B. C. (2015). Storytelling and witty words use in informal learning as a tool for entrepreneurial spirit promotion among Yoruba children. CARESON Journal of Research and Development, 7(1\&2), 159-175.

United Nations. (1992). Report of the United Nations conference on environment and development. Retrieved from https://sustainabledevelopment.un.org/content/documents/Agenda21.pdf

Elizabeth Aanuoluwapo Ajayi ${ }^{3}$, Adekunle Olatumile ${ }^{4}$

Adekunle Ajasin University Akungba-Akoko, Ondo State, Nigeria

\section{Procena narodnih umotvorina}

\section{autohtonih naroda u svrhe promovisanja transformativnog učenja sa ciljem unapređenja ekološke održivosti u Nigeriji}

Apstrakt: Postoje brojni primeri neodrživih praksi vezanih za životnu sredinu, iako su napori uglavnom usredsređeni na formalne strategije. Međutim, postoje i lokalne strategije koje mogu da imaju transformativnu ulogu, kao što su narodne umotvorine autohtonih naroda koje se pretežno dovode u vezu sa starijim ženama. Ova studija predstavlja procenu narodnih umotvorina naroda Joruba kao mogućeg instrumenta za promovisanje transformativnog učenja o ekološkoj održivosti. Ona je primenila model transverzalnog istraživanja sa 200 starijih žena iz deset zajednica savezne države Ondo na severu Nigerije. Studija je obuhvatala šest istraživačkih pitanja, a na njih je odgovarano deskriptivno u okviru strukturiranog intervjua. Između ostalog, utvrđeno je da narodne umotvorine autohtonih naroda koje su naklonjene životnoj sredini imaju potencijal da podstaknu savestan i kritičan osvrt na životnu sredinu i da pomognu u razvoju akcionog plana s ciljem ekološke održivosti. Između ostalog, ovaj rad sadrži preporuku da narodne umotvorine treba da se uključe u sve napore usmerene na ekološku održivost uz podršku starijih žena.

Ključne reči: starije žene, obrazovanje o životnoj sredini, narodne umotvorine autohtonih naroda, transformativno učenje, ekološka održivost.

\footnotetext{
${ }^{3}$ Elizabeth Aanuoluwapo Ajayi je doktorand na Univerzitetu u Beninu i predavač na Fakultetu za obrazovanje Univerziteta Adekunle Ajasin Akungba-Akoko, Nigerija.

${ }^{4}$ Adekunle Olatumile predavač na Fakultetu za obrazovanje Univerziteta Adekunle Ajasin Akungba-Akoko, Nigerija.
} 